\title{
PENGARUH BEBERAPA JENIS SITOKININ PADA MULTIPLIKASI TUNAS ANGGREK Vanda douglas SECARA IN VITRO
}

\section{The Effect of Several Types of Cytokinin on Shoot Multiplication of Vanda douglas Orchid In Vitro}

\author{
Karyanti \\ Balai Bioteknologi BPPT. Gedung 630 Kawasan PUSPIPTEK, Tangerang Selatan, Banten 15314 \\ Email: karyanti@bppt.go.id
}

\begin{abstract}
The study was aimed to determine the response of Vanda douglas orchid on shootmultiplication media to different cytokinin concentrations in vitro. A completely randomized design experiment was employed with one factor cytokinin, in which the cytokinins used were TDZ (thidiazuron), BAP (6-Benzylaminopurine) and kinetin at the concentrations of 0 , $0.5,1$, and $1.5 \mathrm{mg} / \mathrm{L}$. The results showed that kinetin $0.5 \mathrm{mg} / \mathrm{L}$ was the best concentration for shoot formation, occuring on average at 14.88 days after planting; while TDZ $0.5 \mathrm{mg} / \mathrm{L}$ was the best concentration for increasing the height of the plant, being on average $0.53 \mathrm{~cm}$. TDZ at $0.5 \mathrm{mg} / \mathrm{L}$ concentration also had positive effect on shoot and leaf formation, which resulted in the highest number of shoots and leaves. The average number of shoots was 8.00 buds, and the average number of leaves was 12.25 sheets.
\end{abstract}

Keywords: Vanda douglas, thidiazuron, BAP, kinetin, shoots multiplication

\begin{abstract}
ABSTRAK
Penelitian ini bertujuan untuk mengetahui respon anggrek Vanda douglas terhadap media perbanyakan tunas pada beberapa konsentrasi jenis sitokinin secara in vitro. Penelitian ini menggunakan Rancangan Acak Lengkap (RAL) dengan satu faktor, yaitu sitokinin. Sitokinin yang digunakan adalah TDZ (thidiazuron), BAP (6-Benzylaminopurine) dan kinetin, dengan konsentrasi $0,0,5,1$, dan 1,5 mg/L. Hasil penelitian menunjukkan bahwa pemberian kinetin $0,5 \mathrm{mg} / \mathrm{L}$ menunjukkan hasil terbaik pada peubah waktu pembentukan tunas, dengan ratarata 14,88 hari setelah tanam. Sedangkan konsentrasi TDZ 0,5 mg/L merupakan jenis sitokinin dan konsentrasi terbaik terhadap pertambahan tinggi tanaman, dengan rata-rata $0,53 \mathrm{~cm}$. TDZ dengan konsentrasi $0,5 \mathrm{mg} / \mathrm{L}$ juga berpengaruh positif terhadap pertumbuhan tunas dan daun, dengan menghasilkan jumlah tunas tertinggi dan jumlah daun terbanyak. Rata-rata jumlah tunas adalah 8,00 tunas, dan rata-rata jumlah daun adalah 12,25 helai.
\end{abstract}

Kata Kunci: Vanda douglas, thidiazuron, BAP, kinetin, perbanyakan tunas 


\section{PENDAHULUAN}

Tanaman anggrek dengan segala keunikannya yang memukau, telah menarik perhatian para penggemar tanaman hias sejak dua abad yang lalu. Anggrek merupakan salah satu jenis tanaman hias yang mempunyai keindahan bunga yang unik dan daya tahan bunga yang cukup lama jika dibandingkan dengan tanaman lainnya. Keindahan dan daya tarik anggrek terletak pada bentuk dan warna bunganya yang beranekaragam. Sifat-sifat bunga yang demikian ini menyebabkan anggrek banyak disenangi dan ditanam baik oleh para pengusaha tanaman hias maupun para penggemar anggrek (Rosdiana 2010).

Menurut Lubis (2010) Indonesia terkenal sebagai negara yang memiliki banyak spesies anggrek alam. Diperkirakan setengah dari spesies ini terdapat di Papua, sedangkan 2.000 spesies lainnya terdapat di Kalimantan dan sisanya tersebar di pulaupulau lain di Indonesia. Ekspor dan impor anggrek Indonesia terdiri atas tiga bentuk, yaitu bibit, tanaman, dan bunga potong. Upaya pemerintah untuk mendorong pengembangan anggrek di Indonesia sudah dilakukan melalui peningkatan ekspor nonmigas. Namun upaya tersebut belum menunjukkan hasil, yaitu meningkatnya ekspor komoditas anggrek. Diharapkan anggrek dapat meningkatkan pendapatan petani dan sebagai sumber devisa negara. (Widiastoety dan Nurmalinda 2010).

Anggrek Vanda merupakan salah satu jenis anggrek yang sangat popular di kalangan masyarakat luas. Keindahan dan kecantikan Vanda banyak dipuja-puji orang. Kata "vanda" sendiri berasal dari bahasa Sanskrit yang artinya indah. William Roxburgh adalah orang yang berjasa menemukan spesies anggrek Vanda pertama kali, pada tahun 1795. Namanya lalu diabadikan pada spesies tersebut, Vanda tessellata Roxb. Saat ini, terdapat lebih dari 40 spesies Vanda yang kita kenal. Salah satunya adalah Vanda tricolor yang saat ini sedang gencar dikembalikan ke alam, atau Vanda teres yang berdaun pensil. Vanda yang popular di negara tetangga kita adalah Vanda Miss Joaquim yang bahkan dijadikan sebagai bunga nasional Singapura. Vanda tersebut sebenarnya merupakan hasil persilangan antara Vanda hookeriana dengan
Vanda teres pada tahun 1893 di kebun anggrek Joaquim di Singapura. Anggrek Vanda mempunyai penggemar yang tidak kalah banyak dibandingkan anggrek lainnya. Hal ini dikarenakan warna bunga anggrek Vanda sangat beraneka ragam dan bunganya tahan lama (Purwanto dan Semiarti 2009).

Menurut Karyanti (2014) anggrek Vanda douglas merupakan salah satu jenis anggrek yang potensial. Kajian mengenai anggrek $V$. douglas ini masih sangat terbatas. Dalam pembibitan anggrek menurut Rupawan et al. (2014) hingga saat ini perbanyakan anggrek secara in vitro terbukti lebih ampuh dalam penyediaan bibit anggrek yang lebih banyak, seragam dan dalam waktu yang relatif singkat.

Dalam kultur jaringan, media merupakan salah satu faktor penentu keberhasilan perbanyakan tanaman secara kultur jaringan (Zulkarnain 2011). Menurut Nurheti (2010) media MS (Murashige dan Skoog) merupakan media yang banyak digunakan saat ini. Media ini mengandung garam dan nitrat dengan kosentrasi yang lebih tinggi dibandingkan dengan media lain. Faktor yang paling sulit ditentukan dalam kultur jaringan adalah jenis dan konsentrasi zat pengatur tumbuh yang sesuai. Penelitian ini bertujuan untuk mendapatkan jenis dan konsentrasi zat pengatur tumbuh yang tepat untuk perbanyakan tunas anggrek $V$. douglas secara in vitro.

\section{BAHAN DAN METODE}

\section{Penelitian ini dilaksanakan di Laboratorium Kultur Jaringan Balai Bioteknologi-BPPT yang berlokasi di kawasan Puspiptek, Kota Tangerang Selatan, Banten.}

Bahan tanam yang digunakan dalam penelitian ini adalah eksplan steril anggrek $V$. douglas. Bahan media yang digunakan adalah media dasar MS dan beberapa zat pengatur tumbuh (ZPT) jenis sitokinin dengan berbagai dosis sesuai perlakuan, air steril, deterjen, alkohol $70 \%$ dan $96 \%$, media MS dengan setengah konsentrasi, amonium nitrat, tisu steril dan kertas kode.

Alat-alat yang digunakan gelas piala, gelas ukur, $\mathrm{pH}$ meter, medium dispenser, autoklap, shaker, pinset, mata pisau, gunting, scalpel, laminar air flow, stopwatch dan semprotan. Eksplan steril yang telah 
Tabel 1. Perlakuan sitokinin untuk perbanyakan tunas anggrek $V$. douglas secara in vitro

\begin{tabular}{lc}
\hline Kode & Perlakuan \\
\hline A0 & Tanpa ZPT (kontrol) \\
A1 & TDZ $0,5 \mathrm{mg} / \mathrm{L}$ \\
A2 & TDZ $1,0 \mathrm{mg} / \mathrm{L}$ \\
A3 & TDZ $1,5 \mathrm{mg} / \mathrm{L}$ \\
A4 & BAP $0,5 \mathrm{mg} / \mathrm{L}$ \\
A5 & BAP $1,0 \mathrm{mg} / \mathrm{L}$ \\
A6 & BAP $1,5 \mathrm{mg} / \mathrm{L}$ \\
A7 & kinetin $0,5 \mathrm{mg} / \mathrm{L}$ \\
A8 & kinetin $1,0 \mathrm{mg} / \mathrm{L}$ \\
A9 & kinetin $1,5 \mathrm{mg} / \mathrm{L}$ \\
\hline
\end{tabular}

ditanam dalam media perlakuan diinkubasi dalam ruang kultur pada temperatur sekitar $25-26^{\circ} \mathrm{C}$ dengan intensitas cahaya $1000-$ 1500 lux selama 12 jam.

Penelitian ini menggunakan Rancangan Acak Lengkap (RAL) satu faktor dengan modifikasi ZPT sitokinin (A). Ada 3 jenis ZPT yang digunakan, yaitu TDZ (thidiazuron), BAP (6-Benzylaminopurine) dan kinetin, yang masing-masing terdiri dari 3 taraf konsentrasi (Tabel 1). Masing-masing perlakuan diulang sebanyak 8 kali sehingga terdapat 80 satuan percobaan. Model matematika untuk rancangan tersebut adalah:

$$
\mathrm{Y}_{\mathrm{ij}}=\mu+\tau_{\mathrm{i}}+\varepsilon \mathrm{ij}
$$

Dimana,

$$
\begin{aligned}
& i=1,2,3,4,5,6,7,8,9,10 \\
& j=1,2,3,4,5,6,7,8
\end{aligned}
$$

Keterangan:

$$
\begin{aligned}
Y_{i j}= & \text { Nilai pengamatan pada perlakuan } \\
& \text { konsentrasi sitokinin ke-i pada } \\
& \text { ulangan ke-j }
\end{aligned}
$$
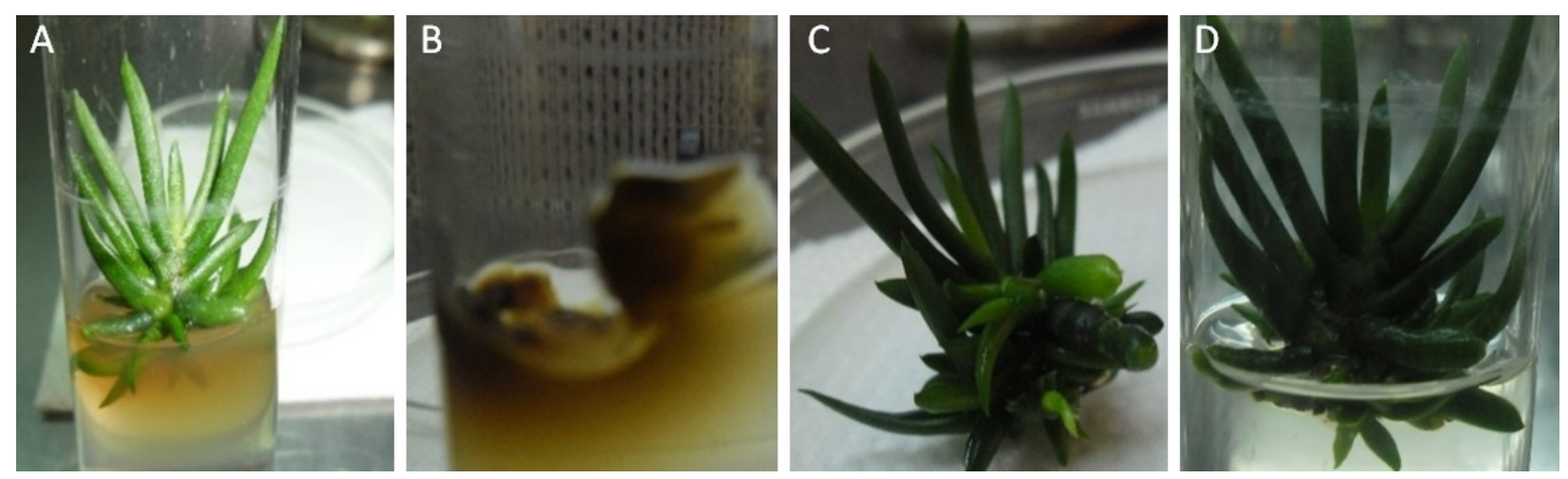

Gambar 1. Kondisi tanaman umur 7 MST (minggu setelah tanam) (A), media berubah menjadi kecoklatan (B), eksplan dikeluarkan dari tabung (C), dan dilakukan subkultur ke media baru (D) 
Kendala lainnya dalam penelitian ini adalah pertumbuhan dari eksplan $V$. douglas yang lambat pada peubah tinggi tunas, menyebabkan data pertumbuhan yang rendah. Hal ini diduga karena kosentrasi perlakuan yang digunakan dan kandungan ZPT endogen yang ada tidak memicu ke arah pertumbuhan tinggi tanaman tetapi ke arah perkembangan yang lain seperti jumlah daun dan jumlah tunas. Menurut Suhentaka (2010) tanaman yang berbeda dapat memberi respon terhadap hormon (sitokinin dan auksin) dalam berbagai konsentrasi secara berbeda pula. Hal ini disebabkan oleh perbedaan dari kandungan konsentrasi hormon endogen tanaman itu sendiri. Adanya pengaruh penambahan zat pengatur tumbuh pada tanaman memiliki respon yang berbeda pada setiap pertumbuhan dan perkembangan spesies tanaman. Begitu pula menurut Gunawan (2007) bahwa pola perkembangan tanaman kultur jaringan dipengaruhi oleh jenis, jumlah dan perbandingan zat-zat pengatur tumbuh yang digunakan. Disamping itu, lambatnya pertumbuhan dan perkembangan tanaman juga diduga terjadi karena eksplan tidak disubkultur sehingga mempengaruhi daya tumbuh tunas. Menurut Dalton dan Dale (1981), daya multiplikasi tunas dipengaruhi oleh frekuensi subkultur yang dilakukan, dan sebaiknya setiap 4-5 minggu dilakukan subkultur.

\section{Waktu pembentukan tunas}

Peubah waktu pembentukan tunas dilakukan mulai dari tunas pertama tumbuh pada setiap eksplan yang ditanam. Peubah ini diamati untuk melihat pada hari ke berapa saat tunas pertama muncul.

Berdasarkan hasil di atas terlihat bahwa waktu pembentukan tunas tercepat terdapat pada perlakuan A7 dengan konsentrasi kinetin $0,5 \mathrm{mg} / \mathrm{L}$ yaitu rata-rata waktu induksi tunas 14,88 HST (hari setelah tanam) sedangkan waktu induksi terlama yaitu pada perlakuan A6 dengan konsentrasi BAP $1,5 \mathrm{mg} / \mathrm{L}$ dengan ratarata waktu induksi 44,63 HST. Kinetin adalah kelompok sitokinin yang berfungsi untuk pengaturan pembelahan sel dan morfogenesis. Dalam pertumbuhan jaringan, sitokinin bersama-sama dengan auksin memberikan pengaruh interaksi terhadap deferensiasi jaringan (Lestari 2011). Menurut Zulkarnain (2011), pertumbuhan tunas dipengaruhi oleh tiga faktor yaitu eksplan, media, dan lingkungan. Dalam kultur jaringan kebanyakan tanaman membutuhkan sitokinin untuk memperbanyak tunas dan daun, hal ini sesuai jika dibandingkan pada perlakuan tanpa menggunakan zat pengatur tumbuh sitokinin, dimana tunas muncul pada umur 30,63 HST.

\section{Tinggi tanaman}

Tanaman akan mengalami pertumbuhan dan perkembangan karena ketersediaan nutrisi pada media, salah satu penanda adanya pertumbuhan adalah tinggi tanaman mengalami peningkatan. Menurut Artina (2014) tinggi tanaman merupakan

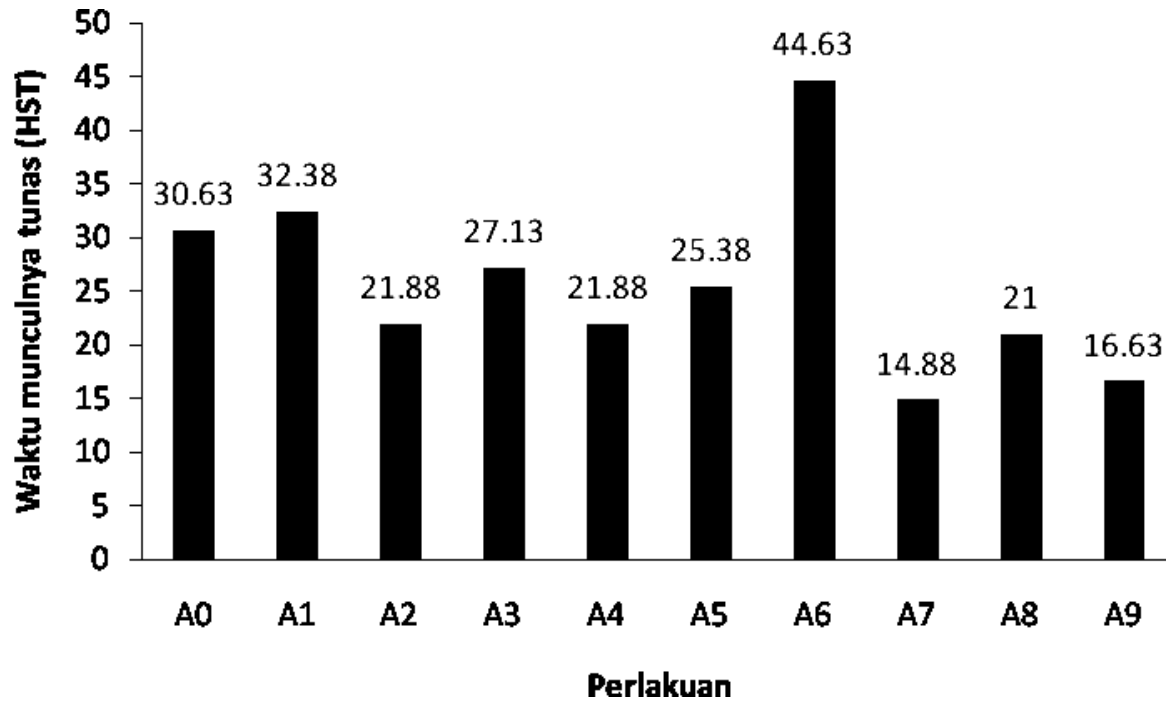

Gambar 2. Pengaruh beberapa jenis dan konsentrasi zat pengatur tumbuh sitokinin terhadap waktu pembentukan tunas tanaman anggrek $V$. douglas 
Tabel 2. Pengaruh beberapa jenis dan konsentrasi zat pengatur tumbuh sitokinin terhadap tinggi tanaman anggrek V. douglas

\begin{tabular}{lcccc}
\hline \multirow{2}{*}{ Perlakuan } & \multicolumn{4}{c}{ Rerata $(\mathrm{cm})$} \\
\cline { 2 - 5 } A0 (KONTROL) & 1 MST & 4 MST & 8 MST & 12 MST \\
A1 (TDZ 0,5 mg/L) & 0,36 & 0,38 & 0,46 & 0,51 \\
A2 (TDZ 1,0 mg/L) & 0,40 & 0,43 & 0,56 & 0,61 \\
A3 (TDZ 1,5 mg/L) & 0,33 & 0,33 & 0,40 & 0,48 \\
A4 (BAP 0,5 mg/L) & 0,36 & 0,45 & 0,51 & 0,54 \\
A5 (BAP 1,0 mg/L) & 0,41 & 0,41 & 0,50 & 0,55 \\
A6 (BAP 1,5 mg/L) & 0,43 & 0,43 & 0,46 & 0,53 \\
A7 (KIN 0,5 mg/L) & 0,40 & 0,43 & 0,49 & 0,56 \\
A8 (KIN 1,0 mg/L) & 0,43 & 0,43 & 0,46 & 0,53 \\
A9 (KIN 1,5 mg/L) & 0,41 & 0,41 & 0,48 & 0,51 \\
\hline
\end{tabular}

peubah yang sering diamati baik sebagai indikator pertumbuhan maupun untuk mengukur pengaruh lingkungan atau perlakuan yang diterapkan. Pertambahan tinggi tanaman dapat digunakan untuk menggambarkan pola laju pertumbuhan selama periode kultur. Selain itu, menurut Anwar (2007) tinggi tanaman merupakan ukuran pertumbuhan yang paling mudah dilihat. Pada penelitian ini tinggi tanaman diukur dari permukaan media kultur sampai titik tumbuh pada dinding tabung kultur karena tanaman tidak boleh dikeluarkan dari tabung kultur. Pengukuran dilakukan setiap minggu dari 1 MST sampai 12 MST.

Berdasarkan rekapitulasi sidik ragam (Tabel 2) pertambahan tinggi tanaman tidak berpengaruh nyata pada saat umur $1,4,8$, dan 12 MST. Hal ini diduga pemberian sitokinin justru tidak berpengaruh nyata pada peubah tinggi tanaman anggrek $V$. douglas. Menurut Widiastoety dan Nurmalinda (2010) pemanjangan batang terjadi karena adanya proses pembelahan, pemanjangan dan pembesaran sel-sel baru yang terjadi pada meristem ujung batang yang mengakibatkan tanaman bertambah tinggi. Pertumbuhan dan morfogenesis tanaman secara in vitro dikendalikan oleh keseimbangan dan interaksi dari zat pengatur tumbuh yang berada dalam eksplan dan akan menentukan arah dari pengembangan kultur.

Berdasarkan hasil analisa (Tabel 2) diperoleh hasil tinggi eksplan pada umur 1, 4, 8, 12 MST pada perlakuan TDZ, BAP, kinetin (A0-A9) tidak berpengaruh nyata. Hal ini diduga karena konsentrasi sitokinin yang digunakan tidak saling menguatkan dengan hormon endogen yang terdapat dalam tanaman aggrek $V$. douglas. Menurut Tuhuteru et al. (2012) zat pengatur tumbuh pada eksplan tergantung dari zat pengatur tumbuh endogen. Respon yang muncul tergantung kemampuan eksplan dalam menyerap dan menggunakan zat pengatur tumbuh endogen yang ada dan ZPT eksogen yang diserap dari media tumbuh. Hal ini sesuai dengan penelitian Sukma dalam Artina (2014) tentang pengaruh BAP atau kinetin terhadap pertumbuhan daun, menunjukkan bahwa BAP atau kinetin sebagai salah satu jenis sitokinin lebih berfungsi untuk mendorong pembentukan tunas, menghambat pertambahan tinggi, sehingga menekan jumlah daun. Menurut Kusmianto (2008) penggunaan sitokinin pada konsentrasi tinggi dapat mengganggu penyerapan unsur hara serta menghambat pertumbuhan eksplan.

\section{Jumlah tunas}

Pengamatan jumlah tunas dilakukan setiap 4 minggu, selama 12 minggu. Pengamatan jumlah tunas yaitu dengan menghitung tunas-tunas yang tumbuh pada setiap eksplan. Pada peubah jumlah tunas dapat dilihat berdasarkan rekapitulasi sidik ragam (Tabel 3) yang menunjukkan berpengaruh nyata pada perlakuan A1 (TDZ0,5 mg/L). Perlakuan ini menunjukkan 
Tabel 3. Pengaruh beberapa jenis dan konsentrasi zat pengatur tumbuh sitokinin terhadap jumlah tunas tanaman anggrek $V$. douglas

\begin{tabular}{lcccc}
\hline \multirow{2}{*}{ Perlakuan } & \multicolumn{4}{c}{ Rerata (Tunas) } \\
\cline { 2 - 5 } & $1 \mathrm{MST}$ & $4 \mathrm{MST}$ & $8 \mathrm{MST}$ & $12 \mathrm{MST}$ \\
\hline A0 (KONTROL) & 0,38 & 0,63 & 0,88 & $1,38 \mathrm{~b}$ \\
A1 (TDZ 0,5 mg/L) & 0,25 & 0,25 & 3,63 & $8,00 \mathrm{a}$ \\
A2 (TDZ 1,0 mg/L) & 0,13 & 0,25 & 0,88 & $1,25 \mathrm{~b}$ \\
A3 (TDZ 1,5 mg/L) & 0,13 & 0,25 & 1,88 & $2,50 \mathrm{~b}$ \\
A4 (BAP 0,5 mg/L) & 0,25 & 0,75 & 2,25 & $4,75 \mathrm{~b}$ \\
A5 (BAP 1,0 mg/L) & 0,25 & 0,63 & 1,25 & $2,25 \mathrm{~b}$ \\
A6 (BAP 1,5 mg/L) & 0,13 & 0,38 & 1,50 & $3,63 \mathrm{~b}$ \\
A7 (KIN 0,5 mg/L) & 0,00 & 1,00 & 1,38 & $2,00 \mathrm{~b}$ \\
A8 (KIN 1,0 mg/L) & 0,13 & 0,88 & 1,00 & $2,13 \mathrm{~b}$ \\
A9 (KIN 1,5 mg/L) & 0,25 & 0,88 & 1,88 & $2,50 \mathrm{~b}$ \\
\hline
\end{tabular}

respon yang baik untuk menginduksi tunas anggrek $V$. douglas sehingga jumlah tunas yang dihasilkan lebih banyak dibanding jenis sitokinin lainnya. Waktu yang dibutuhkan terjadinya induksi tunas cukup lama yaitu lebih dari 8 MST. Hal ini diduga karena adanya fenolik yang mengakibatkan browning sehingga menghambat pertumbuhan tunas. Menurut Khawar et al. (2004) thidiazuron adalah senyawa sitokinin yang dapat menginduksi perbanyakan tunas lebih cepat daripada sitokinin jenis lain. Berikut ini data peubah jumlah tunas yang diamati selama 12 MST.

Pada peubah jumlah tunas TDZ menunjukkan pengaruh nyata pada $12 \mathrm{MST}$. Hal ini diduga terjadi karena thidiazuron merupakan salah satu sitokinin yang lebih aktif dari sitokinin lainnya. Grafik pertumbuhan naik secara signifikan pada minggu akhir pengamatan dengan perlakuan $0,5 \mathrm{mg} / \mathrm{L} \mathrm{TDZ}$, hal ini diduga karena konsentrasi $0,5 \mathrm{mg} / \mathrm{L}$ pada TDZ merupakan konsentrasi yang tepat untuk pertumbuhan anggrek $V$. douglas. Menurut pendapat Sari et al. (2015) bahwa thidiazuron memiliki kemampuan untuk menginduksi kemunculan tunas karena thidiazuron mampu mendorong terjadinya perubahan sitokinin ribonukleotida menjadi lebih aktif. Guo et al. (2011) menjelaskan bahwa thidiazuron berperan menstimulasi produksi sitokinin endogen sel. Selain itu, dikarenakan konsentrasi sitokinin eksogen yang ditambahkan ke dalam media kultur lebih tinggi dibandingkan dengan konsentrasi auksin endogen yang dihasilkan oleh eksplan. Berdasarkan pernyataan Zulkarnain (2011) bahwa interaksi antara zat pengatur tumbuh eksogen dan endogen menentukan arah perkembangan suatu kultur.

\section{Jumlah daun}

Daun merupakan salah satu organ tumbuhan yang paling penting dalam proses fotosintesis umumnya melekat pada batang dan berwarna hijau. Pemberian zat pengatur tumbuh sitokinin berpengaruh nyata pada pembentukan jumlah daun yang terjadi saat 12 MST dengan perlakuan A1 (TDZ 0,5 $\mathrm{mg} / \mathrm{L})$, sedangkan rerata jumlah daun terendah adalah 12,25 (Tabel 4). Thidiazuron merupakan sitokinin yang sebaiknya digunakan dalam konsentrasi yang rendah. Menurut Kusmianto (2008) TDZ memiliki keaktifan lebih baik dibanding sitokinin lain karena berperan dalam menstimulasi produksi sitokinin endogen sel.

\section{KESIMPULAN}

Waktu pembentukan tunas tercepat pada semua perlakuan jenis sitokinin tidak berpengaruh nyata, tetapi berdasarkan data pengamatan penambahan kinetin $0,5 \mathrm{mg} / \mathrm{L}$ (A7) pada rerata 14,88 HST merupakan waktu pembentukan tunas tercepat. Penambahan jenis dan konsentrasi sitokinin (TDZ, BAP, dan kinetin) tidak memberikan pengaruh nyata pada peubah tinggi 
Tabel 4. Pengaruh beberapa jenis dan konsentrasi zat pengatur tumbuh sitokinin terhadap jumlah daun tanaman anggrek $V$. douglas

\begin{tabular}{lcccc}
\hline \multirow{2}{*}{ Perlakuan } & \multicolumn{4}{c}{ Rerata (Helai) } \\
\cline { 2 - 5 } A0 (KONTROL) & $1 \mathrm{MST}$ & $4 \mathrm{MST}$ & $8 \mathrm{MST}$ & $12 \mathrm{MST}$ \\
A1 (TDZ 0,5 mg/L) & 3,38 & 4,00 & 4,25 & $4,75 \mathrm{~b}$ \\
A2 (TDZ 1,0 mg/L) & 4,25 & 4,50 & 7,63 & $12,25 \mathrm{a}$ \\
A3 (TDZ 1,5 mg/L) & 3,00 & 3,13 & 3,88 & $4,25 \mathrm{~b}$ \\
A4 (BAP 0,5 mg/L) & 3,88 & 4,00 & 5,00 & $6,50 \mathrm{~b}$ \\
A5 (BAP 1,0 mg/L) & 3,25 & 3,75 & 5,50 & $8,00 \mathrm{~b}$ \\
A6 (BAP 1,5 mg/L) & 3,38 & 4,00 & 4,63 & $5,75 \mathrm{~b}$ \\
A7 (KIN 0,5 mg/L) & 4,38 & 4,63 & 5,75 & $7,75 \mathrm{~b}$ \\
A8 (KIN 1,0 mg/L) & 2,50 & 3,38 & 3,88 & $4,50 \mathrm{~b}$ \\
A9 (KIN 1,5 mg/L) & 2,63 & 3,25 & 3,63 & $4,75 \mathrm{~b}$ \\
\hline
\end{tabular}

tanaman. Perlakuan TDZ $0,5 \mathrm{mg} / \mathrm{L}$ (A1) berpengaruh nyata pada peubah jumlah tunas pada umur $12 \mathrm{MST}$, dengan rerata tertinggi 8,00 tunas dan jumlah daun dengan rerata 12,25 helai. Perlakuan TDZ pada konsentrasi $0,5 \mathrm{mg} / \mathrm{L}$ adalah media terbaik untuk perbanyakan tunas anggrek $\mathrm{V}$. douglas dibandingkan dengan dua jenis sitokinin yang lain.

\section{DAFTAR PUSTAKA}

Anwar N (2007) Pengaruh media multiplikasi terhadap pembentukan akar pada tunas in vitro nenas (Ananas comosus (L.) Merr.) cv. Smooth Cayenne di media pengakaran. Skripsi, Fakultas Pertanian, Institut Pertanian Bogor

Artina Y (2014) Pengaruh konsentrasi BAP (Benzylaminopurine) dan TDZ (thidiazuron) terhadap inisiasi tunas serta konsentrasi kinetin dan TDZ terhadap multiplikasi tunas tanaman pisang kepok kuning (Musa paradisiaca L.) secara in vitro. Skripsi, Fakultas Pertanian Universitas Sultan Ageng Tirtayasa

Dalton SJ, Dale PJ (1981) Induced tillering of Lolum multiflorum in vitro. Plant Cell Tissue Organ Cult 1:57-64

Gunawan LW (2007) Budidaya Anggrek. Penebar Swadaya, Jakarta

Guo B, Abbasi BH, Zeb A, Xu LL, Wei YH (2011) Thiadiazuron: A multidimensional plant growth regulator. Afr
J Biotechnol 10:8984-9000. doi: 10.5897/AJB11.636

Karyanti (2014) Mengenal "Si Cantik "Vanda Douglas. http://biotek.bppt.go.id/index. php/artikel-sains/123-mengenal-sicantik-anggrek-vanda-douglas. Diakses tanggal 20 Maret 2014

Khawar KM, Sancak C, Uranbey S, Ozcan S (2004) Effect of thidiazuron on shoot regeneration from different explants of lentil (Lens culinaris Medik.) via organogenesis. Turk J Bot 28:421-426

Kusmianto J (2008) Pengaruh thidiazuron tunggal dan kombinasi thidiazuron dan benzyl amino purin terhadap pembentukan tunas dari potongan daun Dendrobium antennatum Lindl secara in vitro. Skripsi, Fakultas MIPA Universitas Indonesia

Lestari EG (2011) Peranan zat pengatur tumbuh dalam perbanyakan tanaman melalui kultur jaringan. J AgroBiogen 7:63-68

Lubis NN (2010) Mikropropagasi tunas anggrek hitam (Coelogyne pandurata Lindl) dengan pemberian Benzil Amino Purin dan Naftalen asam asetat. Skripsi, Universitas Sumatera Utara, Medan

Nurheti Y (2010) Kultur Jaringan Tanaman Skala Rumah Tangga. Andi Publisher, Yogyakarta

Purwanto AW, Semiarti E (2009) Pesona Kecantikan Anggrek Vanda. Percetakan Kanisius, Yogyakarta 
Rosdiana (2010) Pertumbuhan anggrek bulan (Phalaenopsis amboinensis) endemik Sulawesi, pada beberapa jenis dan konsentrasi zat pengatur tumbuh secara in vitro. J Agrisistem 6:88-96

Rupawan IM, Basri Z, Bustami M (2014) Pertumbuhan anggrek Vanda (Vanda sp) pada berbagai komposisi media secara in vitro. e-J Agrotekbis 2:488-494

Santoso U, Nursandi F (2003) Kultur Jaringan Tanaman. Pusbitan UMM, Malang

Sari DI, Suwirmen, Nasir N (2015) Pengaruh konsentrasi thidiazuron (TDZ) dan arang aktif pada sub kultur tunas pisang kepok hijau (Musa paradisiaca L.). Online J Natural Sci 4:280-289

Suhentaka EB (2010) Pengaruh konsentrasi BA dan NAA pada tahap multiplikasi secara in vitro terhadap keberhasilan aklimatisasi nanas (Ananas comosus (L) Merr) kultivar Smooth Cayenne. Skripsi, Fakultas Pertanian, Institut Pertanian, Bogor

Tuhuteru S, Hehanussa ML, Raharjo SHT (2012) Pertumbuhan dan perkembangan anggrek Dendrobium anosmum pada media kultur in vitro dengan beberapa konsentrasi air kelapa. Agrologia 1:1-12

Widiastoety D, Nurmalinda (2010) Pengaruh suplemen nonsintetik terhadap pertumbuhan planlet anggrek Vanda. J Hort 20:60-66

Zulkarnain H (2011) Kultur Jaringan Tanaman: Solusi perbanyakan tanaman budi daya. Bumi Aksara, Jakarta 